\title{
Repurposing of Bromocriptine for Cancer Therapy
}

\author{
Ean-Jeong Seo', Yoshikazu Sugimoto ${ }^{2}$, Henry Johannes Greten ${ }^{3}$ and Thomas Efferth ${ }^{1 *}$ \\ 1 Department of Pharmaceutical Biology, Institute of Pharmacy and Biochemistry, Johannes Gutenberg University, Mainz, \\ Germany, ${ }^{2}$ Division of Chemotherapy, Faculty of Pharmacy, Keio University, Tokyo, Japan, ${ }^{3}$ Abel Salazar Institute \\ of Biomedical Sciences, University of Porto, Porto, Portugal
}

Bromocriptine is an ergot alkaloid and dopamine $D_{2}$ receptor agonist used to treat Parkinson's disease, acromegaly, hyperprolactinemia, and galactorrhea, and more recently diabetes mellitus. The drug is also active against pituitary hormone-dependent tumors (prolactinomas and growth-hormone producing adenomas). We investigated, whether bromocriptine also inhibits hormone-independent and multidrug-resistant (MDR) tumors. We found that bromocriptine was cytotoxic towards drug-sensitive CCRF-CEM, multidrug-resistant CEM/ADR5000 leukemic cells as well as wild-type or multidrug-resistant ABCB5-transfected HEK293 cell lines, but not sensitive or BCRP-transfected multidrug-resistant MDA-MB-231 breast cancer cells. Bromocriptine

OPEN ACCESS

Edited by: Ming Wang,

Phanes Therapeutics, Inc., United States

Reviewed by:

Claudio Sorio,

Università degli Studi di Verona, Italy

Debasish Basak,

University of Arkansas for Medical

Sciences, United States

$\mathrm{TaO} \mathrm{Hu}$,

University of Washington

United States

${ }^{*}$ Correspondence:

Thomas Efferth

efferth@uni-mainz.de

Specialty section:

This article was submitted to Experimental Pharmacology

and Drug Discovery,

a section of the journal

Frontiers in Pharmacology

Received: 16 May 2018 Accepted: 24 August 2018 Published: 08 October 2018

Citation:

Seo E-J, Sugimoto Y, Greten HJ and Efferth T (2018) Repurposing of Bromocriptine for Cancer Therapy.

Front. Pharmacol. 9:1030. doi: 10.3389/fphar.2018.01030 strongly bound to NF-kB pathway proteins as shown by molecular docking and interacted more strongly with DNA-bound NF-kB than free $N F-\kappa B$, indicating that bromocriptine may inhibit NF-кB binding to DNA. Furthermore, bromocriptine decreased

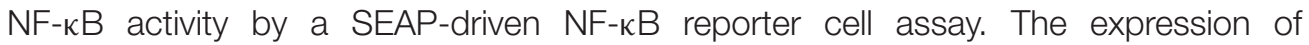
MDR-conferring ABC-transporters (ABCB1, ABCB5, ABCC1, and ABCG2) and other resistance-mediating factors (EGFR, mutated TP53, and $1 \kappa B$ ) did not correlate with cellular response to bromocriptine in a panel of $60 \mathrm{NCl}$ cell lines. There was no correlation between cellular response to bromocriptine and anticancer drugs usually involved in MDR (e.g., anthracyclines, Vinca alkaloids, taxanes, epipodophyllotoxins, and others). COMPARE analysis of microarray-based mRNA expression in these cell lines revealed that genes from various functional groups such as ribosomal proteins, transcription, translation, DNA repair, DNA damage, protein folding, mitochondrial respiratory chain, and chemokines correlated with cellular response to bromocriptine. Our results indicate that bromocriptine inhibited drug-resistant tumor cells with different resistance mechanisms in a hormone-independent manner. As refractory and otherwise drug-resistant tumors represent a major challenge to successful cancer chemotherapy, bromocriptine may be considered for repurposing in cancer therapy.

Keywords: drug repurposing, ergot alkaloids, bromocriptine, neoplasms, pharmacogenomics

\section{INTRODUCTION}

Bromocriptine is an ergot alkaloid and dopamine $\mathrm{D}_{2}$ receptor agonist that has been used to treat Parkinson's disease by affecting dopamine receptor signaling in the nigrostriatal tract and to treat hyperprolactinemia and acromegaly through tuberoinfundibular pathways (Kvernmo et al., 2006). It showed inhibitory effects on serotonin turnover in the central nervous system (CNS; Goldstein, 1980). 
Glucose and energy metabolism is tightly regulated by the CNS in the medial basal hypothalamus (Sandoval et al., 2008). The CNS regulates hepatic glucose production through sympathetic pathways and integrates information via leptin, ghrelin, insulin, glucagon-like pepide-1 (GLP-1), and other hormonal signals. Diabetic and obese patients have damaged responses to these signal pathways and increased hepatic glucose production, insulin resistance, and impaired pancreatic $\beta$-cell function (Defronzo, 2009). A reformulation of bromocriptine for type 2 diabetes was investigated and approved for clinical use (Pijl et al., 2000). The treatment of bromocriptine decreased body weight and improved glucose tolerance in obese people (Cincotta and Meier, 1996). Furthermore, it decreased body fat stores, improved glycemic control, and reduced the need for oral hypoglycemic agents in obese patients with type 2 diabetes (Meier et al., 1992).

Bromocriptine was introduced on the market in 1973 and was used for more than 40 years (Weil, 1986). It is administrated at daily doses of 1.25-80 mg against pituitary hormone-dependent tumors (mainly from prolactinomas and growth-hormone producing adenomas) and at daily doses of 3.75-170 mg against Parkinson's disease (Weil, 1986). Bromocriptine normalizes prolactin and reduces tumor mass in $80-90 \%$ of patients with microadenomas and in $70 \%$ of patients with macroadenomas (Casanueva et al., 2006). Long-term bromocriptine treatment has no harmful effects on hepatic, renal, hematologic, or cardiac functions (Weil, 1986).

Remarkably, bromocriptine's bioactivities are even broader. It exerts inhibitory effects against Chagas disease, which is a tropical parasitic disease caused by the flagellate protozoan Trypanosoma cruzi. Bromocriptine inhibited the cysteine protease cruzipain and thereby the growth of T. cruzi (Bellera et al., 2013).

Drug repurposing is the application of known drugs and compounds for new indications. The interest in this approach is based on the fact that already approved drugs do not need the long and costly development of new drugs to obtain the approval to treat a disease (Ashburn and Thor, 2004). Bromocriptine is widely used against Parkinson's disease for more than 30 years and has been repurposed for the treatment of diabetes. Therefore, it is worth to investigate, whether bromocriptine could be also developed for other diseases.

Nuclear factor kappa-light-chain-enhancer of activated B cells $(\mathrm{NF}-\kappa \mathrm{B})$ has a key role in inflammation. It induces the expression of pro-inflammatory and proliferative interleukins (ILs), tumor necrosis factor (TNF), interferons, and cyclooxygenases on the response to carcinogens, growth factors, and inflammatory stimuli. The NF- $\kappa \mathrm{B}$ complex contains the p50 and p65 subunits. Inactive $\mathrm{NF}-\kappa \mathrm{B}$ binds $\mathrm{I} \kappa \mathrm{B} \alpha$, which is one member of a family of cellular proteins that inhibit NF- $\mathrm{B}$. The

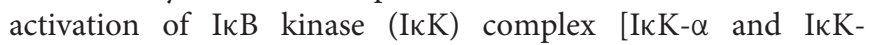
$\beta$ associated with NF- $\kappa \mathrm{B}$ essential modulator (NEMO)] can be induced by binding of ligands to their receptors. NF$\kappa \mathrm{B}$ is an important factor for cell proliferation and cancer progression (Dhanalakshmi et al., 2002; Hayden and Ghosh, 2008).

Bromocriptine was reported to reduce hepatic lipid levels and insulin resistance, which are linked suppressed hyperleptinemia and inhibition of transcription factors and enzymes for lipogenesis and glucongeogenesis, as well as signaling proteins such as suppressor of cytokine signaling 3 (SOCS3), and Jun N-terminal kinase (JNK; Ezrokhi et al., 2014).

Bromocriptine inhibited prolactin-secretion resulting in suppression of lactation and bound to dopamine D2 receptor (Radad et al., 2005). Prolactin exerts both behavioral effects in the brain (Torner et al., 2001; Brunton and Russell, 2010). It induced NF- $\kappa$ B (Rivero-Segura et al., 2017) and exerted antioxidant properties by scavening free oxygen radicals both in vitro and in vivo (Yoshikawa et al., 1994; Muralikrishnan and Mohanakumar, 1998). Increased antioxidant action is one of the most important ways to affect NF- $\mathrm{B}$ (Morgan and Liu, 2011).

In our study, we addressed the question whether bromocriptine is not only active against hormone-dependent tumors but also might exert cytotoxic activity against cancer cells in a hormone-independent fashion. As tumors frequently develop resistance to anticancer drugs, we investigated, whether or not multidrug-resistant (MDR) cells expressing either the ATP-binding cassette $(\mathrm{ABC})$ transporter P-glycoprotein (ABCB1 and MDR1) or ABCB5 exert cross-resistance to bromocriptine. Furthermore, microarray-based mRNA expression data were applied to COMPARE and hierarchical cluster analyses to identify gene expression profiles that correlated with sensitivity or resistance of a panel of 60 tumor cells lines of the National Cancer Institute (NCI), United States, to bromocriptine. Moreover, we investigated the inhibitory effect of bromocriptine toward NF- $\kappa B$ using in silico molecular docking and NF- $\kappa$ B reporter cell assay, since several studies showed that bromocriptine affects NF-кB.

\section{MATERIALS AND METHODS}

\section{Cell Lines}

Drug-sensitive CCRF-CEM and MDR P-glycoproteinoverexpressing CEM/ADR5000 leukemic cells were kindly provided by Prof. Axel Sauerbrey (Department of Pediatrics, University of Jena, Germany). Cells were maintained in RPMI1640 medium supplemented with 10\% fetal bovine serum (FBS) and $1 \%$ penicillin $(1,000 \mathrm{U} / \mathrm{mL}) /$ streptomycin $(100 \mu \mathrm{g} / \mathrm{mL})$ (P/S) (Life Technologies, Darmstadt, Germany). Doxorubicin $(5,000 \mathrm{ng} / \mathrm{mL})$ was added to maintain overexpression of P-gp (MDR1 and ABCB1) in resistant cells (Kimmig et al., 1990). Human embryonic kidney cells (HEK293) were maintained in DMEM + GlutaMAX-I medium (Life Technologies, Darmstadt, Germany) with 10\% FBS and 1\% P/S. The generation of HEK293 derived HEK293-ABCB5 cells has been reported (Kawanobe et al., 2012). Breast cancer cells transduced with a control vecor (MDA-MB-231-pcDNA3) or with cDNA for the breast cancer resistance protein BCRP/ABCG2 (MDA-MB-231-BCRP clone 23) were generated as reported (Doyle et al., 1998). The cell lines were maintained in $800 \mathrm{ng} / \mathrm{mL}$ geneticin (Efferth et al., 2003; Saeed et al., 2015). Cell lines used for cell viability assays are listed in Supplementary Table S1. 


\section{Cell Viability Assay}

The cytotoxic effects of bromocriptine (Sigma-Aldrich, Taufkirchen, Germany; Figure 7A) was evaluated by the resazurin assay (O'Brien et al., 2000). This assay is based on reduction of the indicator dye, resazurin, to the highly fluorescent resorufin by viable cells. Aliquots of 5,000 cells/100 $\mu \mathrm{L}$ of HEK293 and MDA-MB-231 were seeded in 96-well plates and incubated for one day before treatment. However, for leukemic cells, 10,000 cells $/ 100 \mu \mathrm{L}$ cells placed into $96-$ well plates and immediately treated. After $72 \mathrm{~h}$ incubation, $20 \mu \mathrm{L}$ resazurin $0.01 \% \mathrm{w} / \mathrm{v}$ solution were added to each well, and the plates were incubated at $37^{\circ} \mathrm{C}$ for $4 \mathrm{~h}$. Fluorescence was measured by an Infinite M2000 Proplate reader (Tecan, Crailsheim, Germany) using an excitation wavelength of $544 \mathrm{~nm}$ and an emission wavelength of $590 \mathrm{~nm}$. Each experiment was done at least three times with six replicates each. The viability was analyzed based on a comparison with untreated cells. Fifty percent inhibition $\left(\mathrm{IC}_{50}\right)$ values indicate the drug concentrations required to inhibit $50 \%$ of cell proliferation and were calculated from a calibration curve by linear regression using Microsoft Excel (Kuete et al., 2016a,b).

A combination of 20 or $40 \%$ of the $\mathrm{IC}_{50}$ value of bromocriptine (2.4 and $4.8 \mu \mathrm{M}$ ) with different concentrations of doxorubicin or paclitaxel was used to treat CEM/ADR5000 cells.

\section{Statistical Tests}

The Loewe additivity model was applied to evaluate the synergism between bromocriptine and doxorubicin and also between bromocriptine and paclitaxel (Lee et al., 2007). In this model, the combination index $(\mathrm{CI})$ was defined as $\mathrm{CI}=\mathrm{d} 1 / \mathrm{D} 1+$ $\mathrm{d} 2 / \mathrm{D} 2$, where D1 and D2 were the doses of Drug 1 and Drug 2 that caused 50\% inhibition of CEM/ADR5000 cell growth when used alone, $\mathrm{d} 1$ and $\mathrm{d} 2$ were the doses of Drug 1 and Drug 2 in combination, which can generate the same response. If the $\mathrm{CI}$ is equal, less than or more than 1 , the combination dose $(\mathrm{d} 1, \mathrm{~d} 2)$ is termed as additive, synergistic, or antagonistic, respectively. The drug interaction was shown geometrically as isobologram.

\section{Clonogenic Assay}

Clonogenic assays were performed to test the ability of a single cell to grow into a colony after treatment as described before (Franken et al., 2006); $1 \times 10^{6}$ cells of Hek293, Hek293 ABCB5, MDA-MB-231-pcDNA, and MDA-MB-231-BCRP cells were seeded and after $4 \mathrm{~h}$ incubation, varying concentrations of bromocriptine were treated for $72 \mathrm{~h}$. Cells were harvested after treatment and re-plated in 6-well plates immediately after treatment at cell concentrations estimated to yield 50150 colonies/well. Then, cells were cultured for 12 days to allow for colony formation. Cells were fixed in $2 \%$ formaldehyde in PBS for 2 min and the stained with $0.5 \%$ crystal violet in $\mathrm{d} \cdot \mathrm{H}_{2} \mathrm{O}$ for $30 \mathrm{~min}$. Colonies were counted using Image J and survival fraction was determined as explained previously (Franken et al., 2006).

\section{Assessment of the Mode of Action of Bromocriptine by Annexin V-PI Staining}

Cells were treated with $\mathrm{IC}_{50}$ and $2 \times \mathrm{IC}_{50}$ of bromocriptine or with 10 and $20 \mu \mathrm{M}$ doxorubicin for $72 \mathrm{~h}$. Afterward, cells
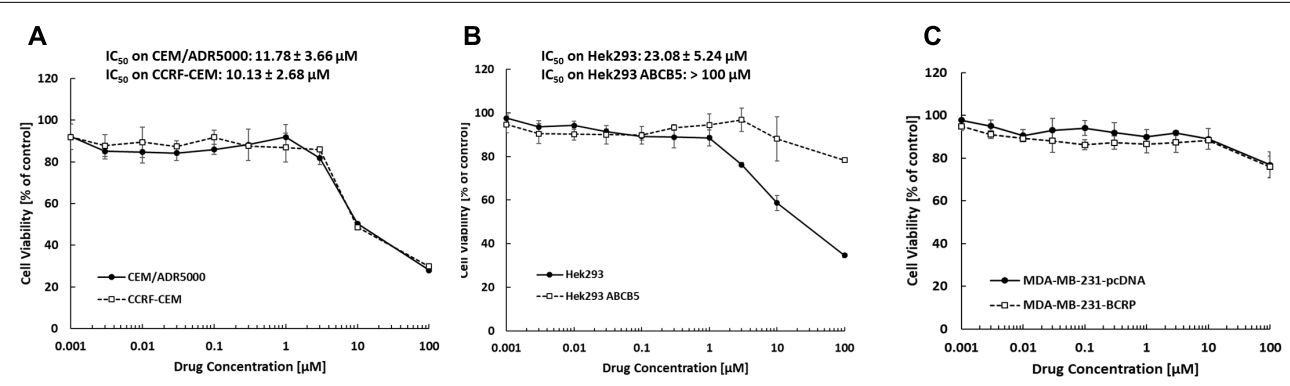

FIGURE 1 | Dose response curves of bromocriptine using the resazurin assay. Cytotoxic effect of bromocriptine against (A) CCRF-CEM and CEM/ADR5000, (B) HEK293 and HEK293 ABCB5, and (C) MDA-MB-231-pcDNA3 and MDA-MB-231-BCRP cells.
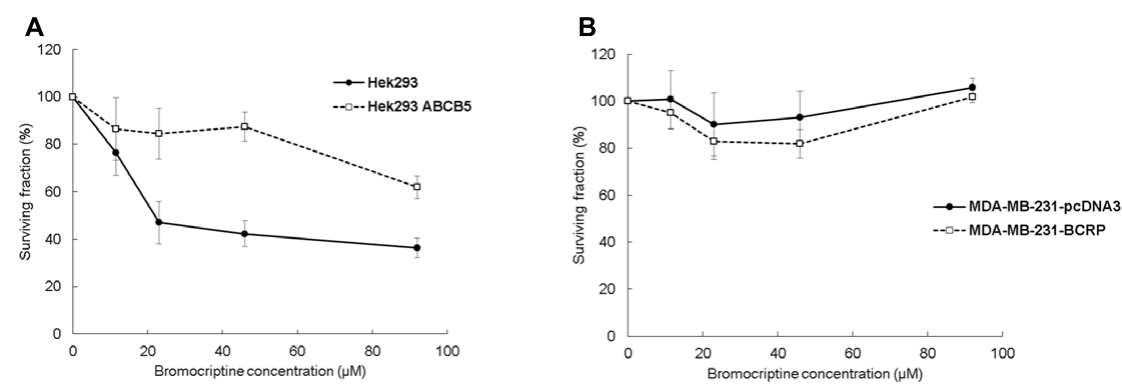

FIGURE 2 | Clonogenic assays for (A) Hek293, Hek293 ABCB5 and for (B) MDA-MB-231-pcDNA and MDA-MB-231-BCRP cells. 
were analyzed by annexin V-PI double staining (Thermo Fisher, Darmstadt, Germany). Annexin V is an intracellular protein that calcium-dependently binds to phosphatidylserine (PS), which translocates from the intracellular leaflet of the plasma membrane to the external leaflet during early apoptosis. Propidium iodide (PI) is excluded by living or early apoptotic cells with intact membranes and stains late apoptotic and necrotic cells with red fluorescence due to DNA intercalation. Therefore, cells with annexin V (-) and PI (-) are considered to be alive, while cells with annexin V (+) and PI (-) are in early apoptosis. Cells in late apoptosis or necrosis are both annexin V and PI positive. Briefly, CCRF-CEM cells were treated with various concentrations of bromocriptine or doxorubicin for $72 \mathrm{~h}$. After incubation, cells were collected by centrifugation. After washing with PBS, cells were incubated with annexin V and PI binding buffer (Thermo Fisher) according to the manufacturer's protocol. Subsequently, $2 \times 10^{4}$ cells were counted and measured with Accuri ${ }^{\mathrm{TM}}$ C6 cytometer (BD Biosciences, Heidelberg, Germany).
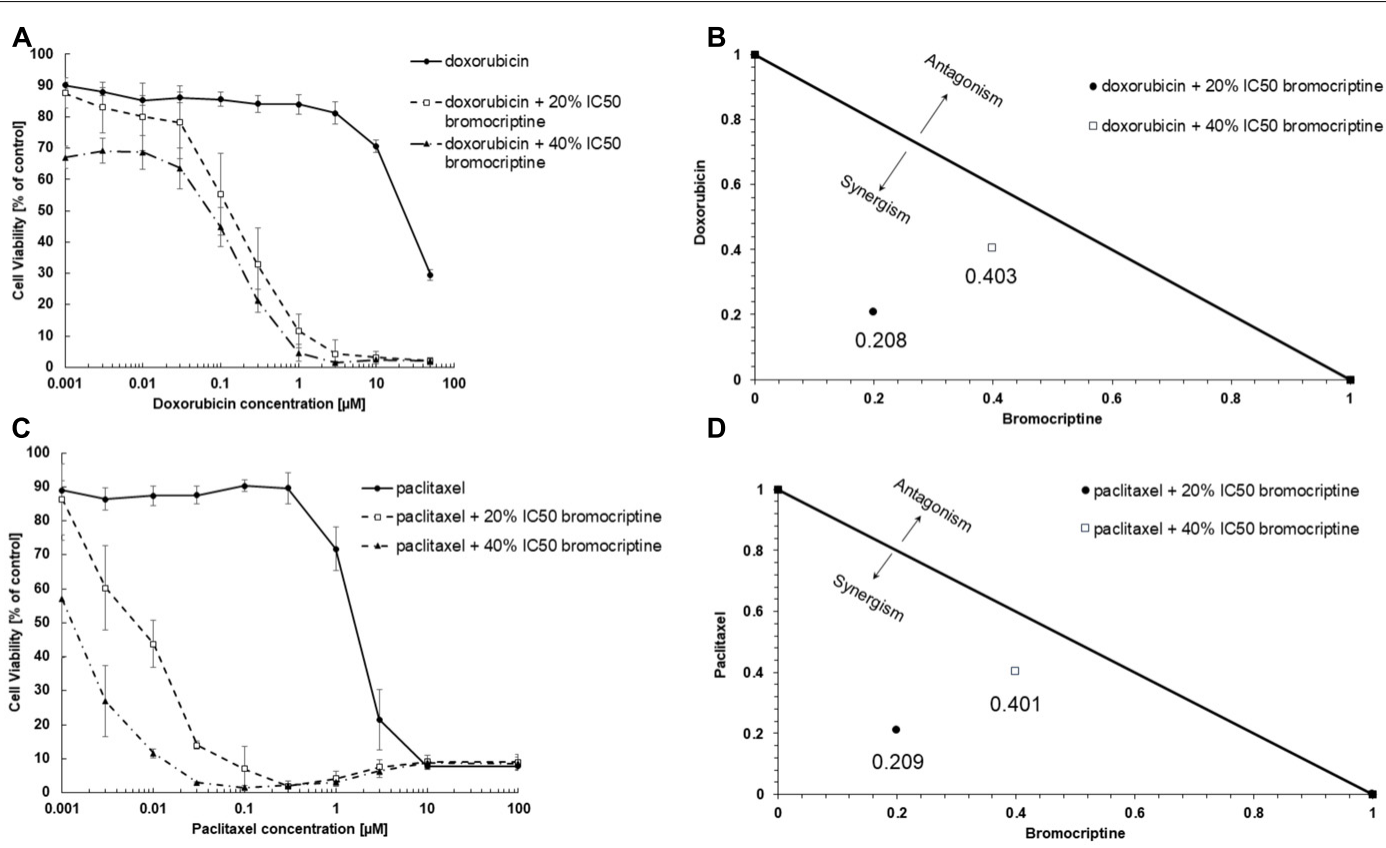

FIGURE 3 | Synergistic effects of bromocriptine with $\mathbf{( A , B )}$ doxorubicin or with (C,D) paclitaxel in CEM/ADR5000 cells as shown in (A,C) dose response curves and (B,D) dose-normalized isobolograms.
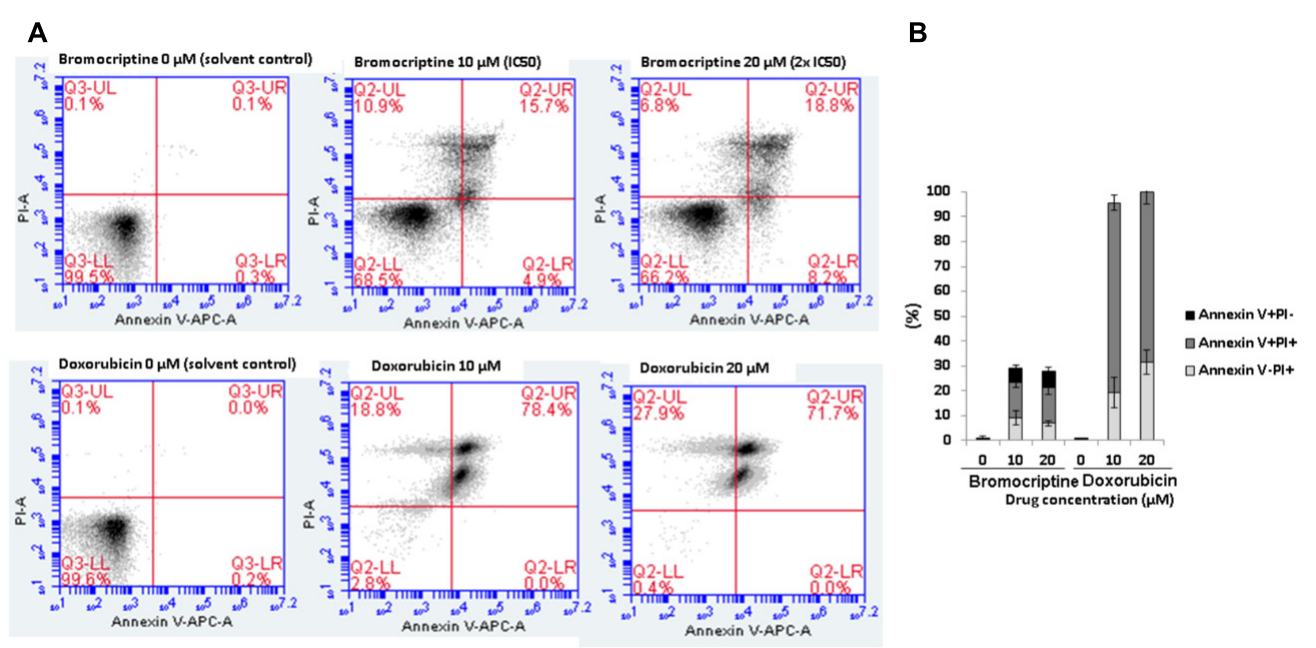

FIGURE 4 | Analysis of cell death in CCRF-CEM cells induced by bromocriptine or doxorubicin. (A) Representative dot plots of flow cytometry analysis after treatment of CCRF-CEM cells with $I_{50}$ or $2 \times I_{50}$ of bromocriptine as well as 10 or $20 \mu \mathrm{M}$ doxorubicin for $72 \mathrm{~h}$. (B) The graph shows mean values $\pm \mathrm{SD}$ of three independent experiments. Annexin $\mathrm{V}-/ \mathrm{Pl}+$ : late necrosis, annexin $\mathrm{V}+/ \mathrm{PI}+$ : late apoptosis or early necrosis, and annexin $\mathrm{V}+/ \mathrm{Pl}-$ : early apoptosis. 
The annexin V-APC signal was measured with $640 \mathrm{~nm}$ excitation and detected using a 675/25 nm bandpass filter. The PI signal was analyzed with $488 \mathrm{~nm}$ excitation and detected using a 585/40 nm bandpass filter. All parameters wee plotted on a logarithmic scale. Cytographs were analyzed using BD Accuri C6 software (BD Biosciences).

\section{COMPARE and Cluster Analyses of Microarray Data}

The mRNA microarray hybridization of the NCI cell lines has been reported at the NCI Web site ${ }^{1}$ (Scherf et al., 2000; Amundson et al., 2008). The cell lines of the NCI panel are shown in Supplementary Table S2. COMPARE analyses were carried out to produce rank ordered lists of genes expressed in the NCI cell lines. The detailed method as a tool to identify candidate genes for drug resistance and sensitivity has been previously reported (Wosikowski et al., 1997; Evans et al., 2008; Fagan et al., 2010; Efferth et al., 2011). In order to obtain COMPARE rankings, a scale index of correlation coefficients ( $R$-values) was created from $\operatorname{Iog}_{10} \mathrm{IC}_{50}$ values of test compounds and microarray-based mRNA expression values. Greater mRNA expression correlated with enhanced drug resistance in the standard COMPARE, whereas greater mRNA expression in cell lines indicated drug sensitivity in reverse COMPARE analyses. Pearson's correlation test was applied to calculate significance values and rank correlation coefficients as a relative measure for the linear dependency of two variables.

For hierarchical cluster analyses, objects were classified by calculation of distances according to the closeness of between individual distances. All objects were assembled into cluster trees (dendrograms). Merging of objects with similar features leads to cluster formation, where the length of the branch indicates the degree of relation. Distances of subordinate cluster branches to superior cluster branches serve as criteria for the closeness of clusters. Therefore, objects with tightly related features were clustered closely together, while separation of objects in the dendrogram increased with progressive dissimilarity. Hierarchical clustering and heat map analyses were performed using clustered image map (CIM) miner software by the one matrix $\mathrm{CIM}^{2}$ (Weinstein et al., 1997).

\section{Molecular Docking}

Molecular docking was performed to predict the interaction energy of bromocriptine with target proteins: $\mathrm{I}-\kappa \mathrm{B}$ kinase $\beta$, I- $\kappa \mathrm{B}$ kinase $\beta$-NEMO complex, NF- $\kappa \mathrm{B}$, and NF- $\kappa \mathrm{B}-\mathrm{DNA}$ complex. The protocol for molecular docking was published by us (Zeino et al., 2014). Protein structures using X-ray crystallography were retrieved from $\mathrm{PDB}$ database $\mathrm{e}^{3}$. I- $\kappa \mathrm{B}$ kinase $\beta$ (PDB ID:3RZF), I- $\kappa$ B kinase $\beta$-NEMO complex (PDB ID:3BRT), NF- $\kappa$ B (p52/RelB heterodimer, PDB ID:3DO7), and NF- $\kappa$ DNA complex (p50/p65 heterodimer bound to DNA, PDB

\footnotetext{
${ }^{1}$ http://dtp.nci.nih.gov

${ }^{2}$ https://discover.nci.nih.gov/cimminer/oneMatrix.do

${ }^{3}$ http://www.rcsb.org/
}

ID:IVKX) were used in our study. A grid box was designed to define docking spaces in each protein according to its pharmacophores. Docking parameters were set to 250 runs and 2,500,000 energy evaluations for each time. Lamarckian genetic algorithm was chosen for docking calculations. For the visualization of docking results, AutodockTools-1.5.7rcl was used. The surface representation image showing the binding pocket of proteins was made with Visual Molecular Dynamics (VMD) software developed with NIH support by the Theoretical and Computational Biophysics group at

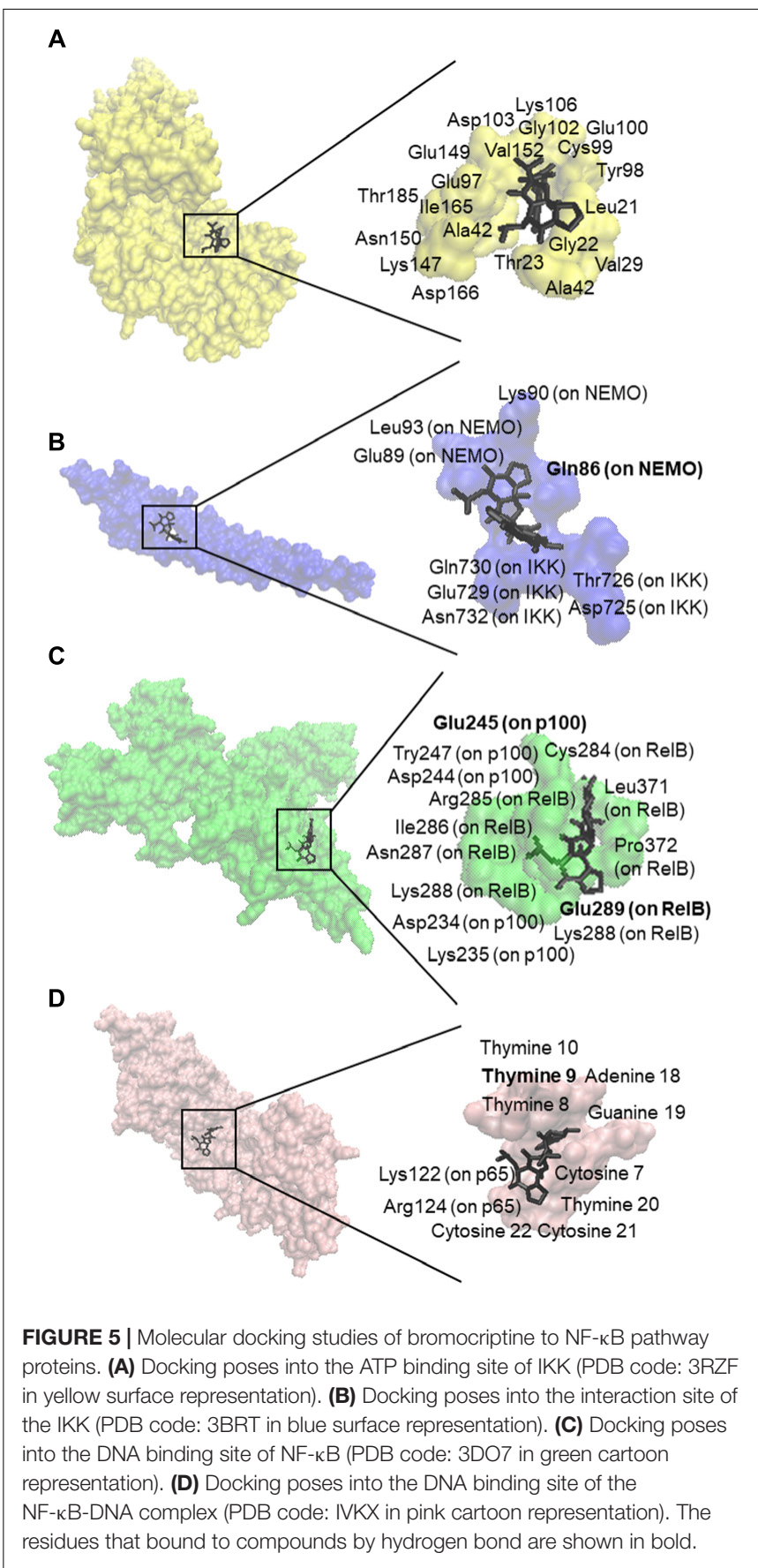


the Beckman Institute, University of Illinois at UrbanaChampaign ${ }^{4}$.

\section{NF-кB Reporter Cell Assay}

HEK293 cells stably expressing HEK-Blue-Null1 vector and SEAP on a NF- $\kappa$ B promoter were purchased from Invivogen (San Diego, CA, United States). The cells were cultured according to manufacturer's protocol and treated with several different concentrations of bromocriptine $(0,20$, and $40 \mu \mathrm{M})$ for $1 \mathrm{~h}$ and bromocriptine was not removed. Afterward, NF- $\kappa \mathrm{B}$ activity was induced with $100 \mathrm{ng} / \mathrm{mL}$ of TNF- $\alpha$ for $24 \mathrm{~h}$. The activation was measured by detecting SEAP spectrophotometrically at $630 \mathrm{~nm}$

${ }^{4}$ http://www.ks.uiuc.edu/Research/vmd/ with addition of Quanti Blue (Invivogen). The procedure has been reported by us (Kadioglu and Efferth, 2015; Kadioglu et al., 2016; Dawood et al., 2018).

\section{RESULTS}

\section{Cytotoxicity of Bromocriptine Against ABC-Transporter Expressing Tumor Cell Lines}

The inhibition of drug-sensitive (CCRF-CEM, HEK293, and MDA-MB-231-pcDNA3) and MDR cell lines (CEM/ADR5000, HEK293-ABCB5, and MDA-MB-231-BCRP) by bromocriptine

TABLE 1 | In silico defined molecular docking of bromocriptine on NF-KB pathway proteins.

\begin{tabular}{|c|c|c|c|c|c|}
\hline Protein & $\begin{array}{l}\text { Lowest energy of } \\
\text { docking (kcal/mol) }\end{array}$ & $\begin{array}{l}\text { Mean binding energy } \\
\text { (kcal/mol) }\end{array}$ & $\begin{array}{l}\text { Residues involved } \\
\text { hydrogen bond } \\
\text { interaction with the } \\
\text { ligand }\end{array}$ & $\begin{array}{l}\text { Residues involved in } \\
\text { hydrophobic } \\
\text { interaction with } \\
\text { ligand }\end{array}$ & pKi (nM) \\
\hline $\begin{array}{l}\text { I-kB kinase } \beta \\
\text { NEMO }\end{array}$ & $-8.47 \pm 0.01$ & $-8.13 \pm 0.07$ & GLY86 & $\begin{array}{l}\text { ASP725, } \\
\text { THR726, } \\
\text { GLU729, } \\
\text { GLN730, } \\
\text { ASN732, GLN86, } \\
\text { GLU89, LYS90, } \\
\text { LEU93 }\end{array}$ & $620.91 \pm 9.47$ \\
\hline NF-кB & $-9.02 \pm 0.03$ & $-8.47 \pm 0.16$ & $\begin{array}{l}\text { GLU245, } \\
\text { GLU289 }\end{array}$ & $\begin{array}{l}\text { CYS284, } \\
\text { ARG285, ILE286, } \\
\text { ASN287, } \\
\text { LYS288, } \\
\text { GLU289, } \\
\text { LEU371, } \\
\text { PRO372, } \\
\text { ASP234, LYS235, } \\
\text { ASP244, } \\
\text { GLU245, } \\
\text { TYR247 }\end{array}$ & $244.41 \pm 11.98$ \\
\hline
\end{tabular}


was investigated using the resazurin assay. The growth of CEM/ADR5000, CCRF-CEM and HEK293 cells was inhibited by treatment with bromocriptine for $72 \mathrm{~h}$. The $\mathrm{IC}_{50}$ values of bromocriptine toward CCRF-CEM and CEM/ADR5000 were 10.13 and $11.78 \mu \mathrm{M}$, respectively (Figure 1A). HEK293 cells were inhibited at concentration of $5.24 \mu \mathrm{M}$ of bromocriptine, while HEK/ABCB 5 transfectants were not inhibited by concentrations up to $100 \mu \mathrm{M}$ (Figure 1B). To test BRCP as another member of the ABC-transporter family, MDA-MB-231 cells transfected with a cDNA coding for BRCP were treated with bromocriptine and compared to mock-vector transfected MDA-MB-231pcDNA3 cells. Bromocriptine did, however, not inhibit the growth of these two cell lines in concentrations up to $100 \mu \mathrm{M}$, indicating that bromocriptine was not active against these cell lines (Figure 1C).

\section{Clonogenic Assays}

Clonogenic assay results were comparable with the results of the resazurin assay. The surviving fraction (\% of control) of Hek293 cells decreased after treatment with bromocriptine, whereas the surviving fraction of Hek293 ABCB5, MDA-MB-231-pcDNA, and MDA-MB-231-BCRP cells was not considerably affected (Figure 2).

\section{Cytotoxic Effects of Combination of Bromocriptine With Doxorubicin or With Paclitaxel}

We tested cytotoxic effects of combination of bromocriptine with doxorubicin or with paclitaxel. The combination of bromocriptine $\left(20 \% \mathrm{IC}_{50}\right.$ and $40 \% \mathrm{IC}_{50}$ ) with doxorubicin or with paclitaxel resulted in synergistic effects in CEM/ADR5000 cells using the Loewe isobologram method (Figure 3).

\section{Induction of Apoptosis by Bromocriptine in CCRF-CEM Cells}

We investigated the action of bromocriptine by annexin V-PI staining (Figure 4). After treatment of CCRF-CEM cells with $\mathrm{IC}_{50}$ or $2 \times \mathrm{IC}_{50}$ concentrations of bromocriptine for $72 \mathrm{~h}$, more than $15 \%$ of cells appeared in late apoptosis (annexin $\mathrm{V}+/ \mathrm{PI}+$ ). Doxorubicin, which was used as cytotoxic control drug, caused dramatic induction of cell death with more than $70 \%$ cells in late apoptosis (annexin V+/PI+; Figure 4).

\section{Inhibition of NF-kB by Bromocriptine}

$\mathrm{NF}-\kappa \mathrm{B}$ represents an important mechanism to many anticancer drugs, because it can inhibit drug-induced apoptosis of chemotherapeutics (Baldwin, 2001; Wu and Bonavida, 2009; Darvishi et al., 2017). Therefore, we were interested to investigate the effect of bromocriptine on this transcription factor.

We first performed in silico molecular dockings, in order to evaluate the binding of bromocriptine to NF- $\kappa \mathrm{B}$ pathway proteins. Interestingly, bromocriptine showed strong interactions with NF- $\mathrm{B}$ pathway proteins (Figure 5 and Table 1). Bromocriptine showed stronger binding to the NF$\kappa \mathrm{B}-\mathrm{DNA}$ complex as NF- $\kappa \mathrm{B}$ alone. The binding energies were $-11.13 \pm 0.21$ with the NF- $\kappa B-D N A$ complex and $-9.02 \pm 0.03$ with NF- $\mathrm{B}$ alone. Bromocriptine formed hydrogen bonds with bound DNA. The drug bound to the ATP-binding site of I- $\kappa$ B kinase $\beta$ with a binding energy of $-9.60 \pm 0.20 \mathrm{kcal} / \mathrm{mol}$. It also docked to the I- $\kappa \mathrm{B}$ kinase $\beta$-NEMO interaction site with a binding energy of $-8.47 \pm 0.21 \mathrm{kcal} / \mathrm{mol}$. Our molecular docking results indicated that bromocriptine strongly bound to NF- $\kappa$ B pathway proteins. Furthermore, binding affinity of bromocriptine was higher to DNA-bound NF- $\kappa \mathrm{B}$ than to free $N F-\kappa B$, indicating that bromocriptine may inhibit DNA binding.

Then, we performed NF- $\mathrm{B}$ reporter cell in vitro assays to confirm the results obtained by molecular docking in silico. Bromocriptine inhibited NF- $\kappa \mathrm{B}$ activity in a dose-dependent manner in the presence of $100 \mathrm{ng} / \mathrm{mL}$ TNF $\alpha$ as NF-кB-inducing agent (Figure 6).

\section{Cytotoxicity of Bromocriptine Toward the $\mathrm{NCl}$ Cell Line Panel}

Protein and mRNA expression as well as DNA mutations of ABC-transporters (ABCB1, ABCB5, ABCC1, and ABCG2) and other mechanisms of drug resistance (EGFR, mutated TP53, $\mathrm{NF} \kappa \mathrm{B}$, and $\mathrm{I} \kappa \mathrm{B})$ in the NCI cell line panel was correlated with the $\log _{10} \mathrm{IC}_{50}$ values for bromocriptine. While statistically significant correlations were not found for bromocriptine (except for $\mathrm{NF}-\kappa \mathrm{B}$ ), the $\log _{10} \mathrm{IC}_{50}$ values of positive control drugs significantly correlated to their corresponding mechanisms of resistance (daunorubicin for $\mathrm{ABCB} 1$, mayansine, for $\mathrm{ABCB}$, vinblastine for $\mathrm{ABC} 1$, pancristatin for $\mathrm{ABCG}$, erlotinib for EGFR, 5-fluoruracil for mutated TP53, and parthenolide for I$\kappa \mathrm{B}$; Table 2). This indicates that bromocriptine is not involved in the drug resistance profiles of these multiple drug resistance mechanisms.

\section{Drug Class Profiling}

To investigate the cross-resistance profile of the NCI cell lines to bromocriptine in more detail, we correlated bromocriptine's $\log _{10} \mathrm{IC}_{50}$ values with those of 89 standard anticancer drugs. The response of $57 \%$ of the anti-hormonal drugs, $36 \%$ of the

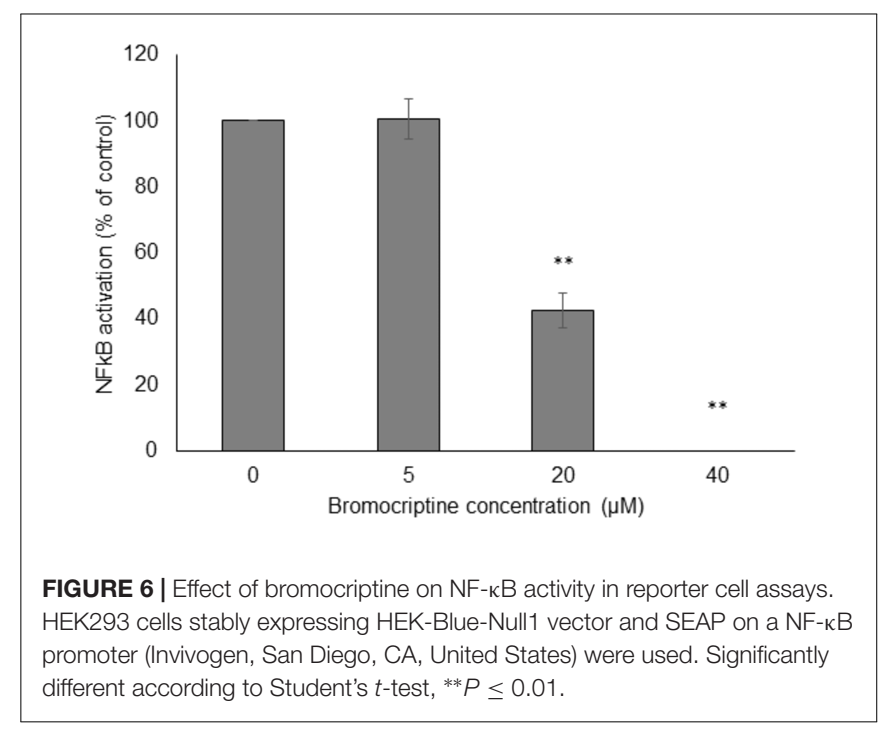


TABLE 2 | Correlation of $\log _{10} I_{50}$ values for bromocriptine to drug resistance mechanisms (ABCB1, ABCB5, ABCC1, ABCG2, EGFR, TP53, NFאB, and IкB) in the NCl cell line panel.

Bromocriptine (log10 IC50, M)

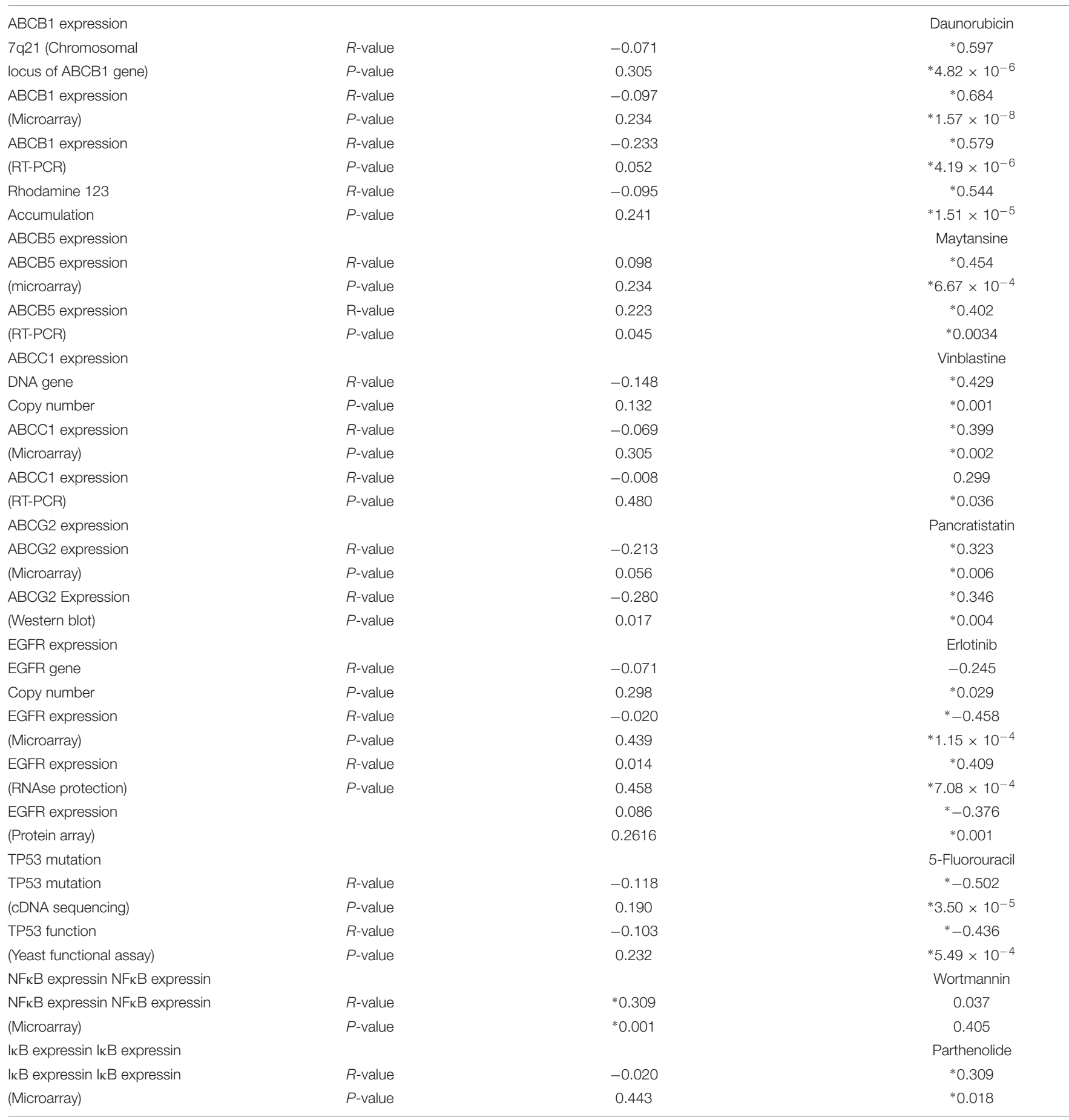

tyrosine kinase inhibitors, $33 \%$ of the platinum compounds, $31 \%$ of the alkylating agents, $20 \%$ of various other drugs, and $7 \%$ of the anti-metabolites significantly correlated with bromocriptine (Figure 7C). The significant correlations between cellular response to bromocriptine and anti-hormonal anticancer drugs were found for fulvestrant, anastrol, megostrol, and raloxifene, but not tamoxifen, toremifen, and exemestane.

Typical drugs involved in ABC-transporter-mediated multidrug resistance phenotypes (e.g., DNA topoisomerase I or II inhibitors, taxanes, Vinca alkaloids, etc.) did not correlate 


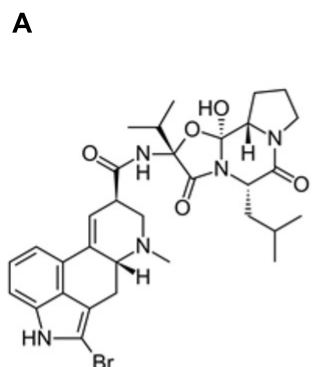

B

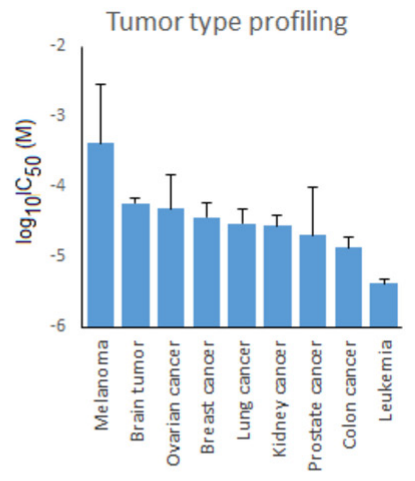

C

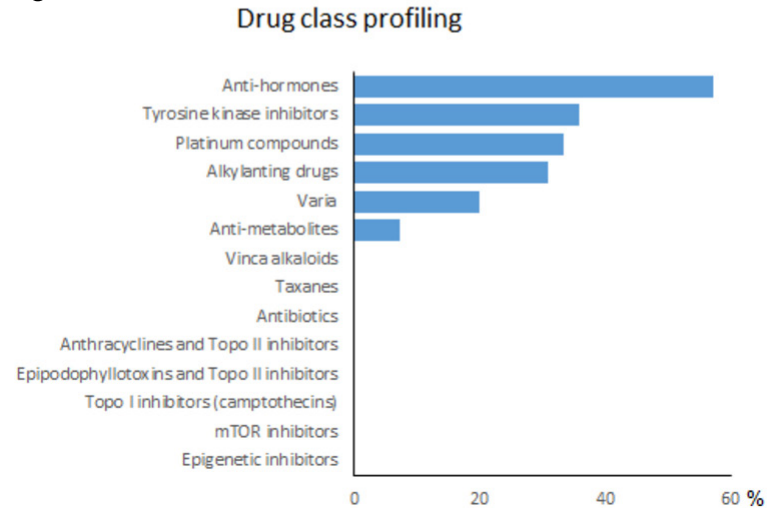

FIGURE 7 | Drug profiling of bromocriptine in the $\mathrm{NCl}$ cell line panel. (A) Chemical structure of bromocriptine. (B) Mean $\log _{10} \mathrm{IC}_{50}$ values for bromocriptine grouped according to the tumor type of the cell lines. (C) Percentage of classes of standard anticancer drugs, whose $\log _{10} I_{5} C_{50}$ values correlated with those for bromocriptine.

with bromocriptine (Figure 7C). This result confirmed the missing correlation of the cellular response of bromocriptine to ABC-transporter expression (Table 2).

\section{Tumor Type-Dependent Response to Bromocriptine}

If the average $\log _{10} \mathrm{IC}_{50}$ values of the NCI cell line panel were diversified according to the tumor type of the cell lines, leukemia and colon carcinomas were most sensitive, whereas melanoma and brain tumors were most resistant to bromocriptine (Figure 7B).

\section{COMPARE and Hierarchical Cluster Analysis of mRNA Microarray Data}

We investigated the transcriptome-wide mRNA expression of the NCI cell lines by COMPARE analysis and correlated the microarray-based mRNA expression data set with the $\log _{10} \mathrm{IC}_{50}$ values for bromocriptine in 60 cell lines of diverse tumor types, in order to identify novel putative factors associated with cellular response to this compound. The scale rankings of genes obtained by COMPARE computation were subjected to Pearson's rank correlation tests. The top 20 genes with direct and the top 20 genes with inverse correlation coefficients are shown in Table 3.

The mRNA expression of these genes was subjected to hierarchical cluster analysis and cluster image mapping (Figure 8). The dendrogram with the cell lines illustrated at the left hand side of the heat map can be divided into four major clusters (Figure 8). We analyzed the distribution of cell lines for their sensitivity toward bromocriptine by the chi-square test (Table 4). The distribution of cell lines being sensitive or resistant was significantly different in the dendogram showing that cellular response to bromocriptine was predictable by this set of mRNA expressions (Figure 8 and Table 4). Cluster 1 contained only sensitive, cluster 2 mainly sensitive, and clusters 3 and 4 mostly resistant cell lines. This distribution of sensitive and resistant cell lines was statistically significant $\left(P=7.03 \times 10^{-5}\right)$. Interestingly, many of the identified genes code for ribosomal proteins (RPL9, RPS24, RPS3A, RPL34, RPS21, RPS27A, RPS15A, RPSA, RPL6, and RPL23A).

\section{DISCUSSION}

Bromocriptine is originally treated for Parkinson's disease, acromegaly, hyperprolactinemia, galactorrhea, and more recently also for diabetes mellitus (Millan et al., 2002; Murteira et al., 2013). It acts as D1 and D2 dopamine receptor agonists, and as D4 dopamine receptor antagonist (Tan and Jankovic, 2001; Millan et al., 2002). Bromocriptine reduces tumor growth by inhibiting synthesis and secretion of prolactin and inhibiting angiogenesis in the tumor environment (Webster, 1999).

In our study, bromocriptine showed cytotoxic effects not only toward drug-sensitive CCRF-CEM, but also MDR P-glycoprotein overexpressing CEM/ADR5000 leukemic cells. Moreover, it was cytotoxic toward HEK293 cells, but only weakly active against HEK-ABCB5 transfectants. Comparable results were obtained by clonogenic assays.

Collateral sensitivity ( = hypersensitivity) is not infrequently seen in ABC-transporter-expressing cells. This phenomenon is known for many years in ABCB1 (P-gp/MDR1) and MRP1overexpressing tumor cells (Hutchison, 1963; Gottesman and Pastan, 1993). Therefore, it is straightforward also to expect drugs that exert collateral sensitivity in ABCB5-expressing cells. The phenomenon for ABCB5 is, however, new, and to the best of our knowledge, the results of the present data are the first. In this respect, the present data are novel.

Collateral sensitivity in other ABC-transporters is mostly caused by excessive consumption of ATP. The collateral sensitive drugs bind to the $\mathrm{ABC}$-transporter. The transporter tries to pump out the drug under consumption of ATP. If this process fails, the transporter tries once more to pump out this molecules under ATP consumption. This process is repeated many times, and the ATP stores in the cells are consumed leading to the death of the cell. Since drug-sensitive wild-type cells do not express the ABC-transporter, this preferential ATP consumption does not take place and the cells are not preferentially killed. This leads to the somewhat paradox situation that MDR ABC-transporter 
TABLE 3 | Correlation of mRNA expression of genes identified by COMPARE analysis with $\log _{10} \mathrm{IC}_{50}$ values of bromocriptine for 60 NCl tumor cell lines ${ }^{a}$.

\begin{tabular}{|c|c|c|c|c|c|}
\hline $\begin{array}{l}\text { COMPARE } \\
\text { coefficient }\end{array}$ & Pattern ID & $\begin{array}{l}\text { GeneBank } \\
\text { accession }\end{array}$ & Gene symbol & Gene name & Gene function \\
\hline 0.642 & GC38764 & X60489 & EEF1B2 & $\begin{array}{l}\text { Eukaryotic translation } \\
\text { elongation factor } 1 \beta 2\end{array}$ & $\begin{array}{l}\text { Stimulates the exchange of GDP bound } \\
\text { to EF1 } \alpha \text { to GTP. }\end{array}$ \\
\hline 0.640 & GC39380 & U09953 & RPL9 & Ribosomal protein L9 & ribosomal protein L9 \\
\hline 0.627 & GC35297 & M31520 & RPS24 & Ribosomal protein S24 & $\begin{array}{l}\text { Required for processing of pre-rRNA } \\
\text { and maturation of } 40 S \text { ribosomal } \\
\text { subunits }\end{array}$ \\
\hline 0.622 & GC33697 & M84711 & RPS3A & Ribosomal protein S3A & $\begin{array}{l}\text { Role during erythropoiesis by regulation } \\
\text { of transcription factor DDIT3 }\end{array}$ \\
\hline 0.616 & GC29122 & AF054183 & RAN & $\begin{array}{l}\text { RAN, member RAS oncogene } \\
\text { family }\end{array}$ & $\begin{array}{l}\text { Mediation of nucleocytoplasmic protein } \\
\text { and ribonucleoprotein transport }\end{array}$ \\
\hline 0.612 & GC36652 & L38941 & RPL34 & Ribosomal protein L34 & 60 S ribosomal protein L34 \\
\hline 0.604 & GC34926 & X79563 & RPS21 & Ribosomal protein S21 & $40 S$ ribosomal protein $\mathrm{S} 21,9 \mathrm{kDa}$ \\
\hline 0.598 & GC37574 & S79522 & $R P S 27 A$ & Ribosomal protein S27a & $\begin{array}{l}60 \text { S ribosomal protein S27A. } \\
\text { Component of the } 40 \text { S subunit of the } \\
\text { ribosome }\end{array}$ \\
\hline 0.596 & GC30163 & AF054187 & NACA & $\begin{array}{l}\text { Nascent } \\
\text { polypeptide-associated } \\
\text { complex } \alpha \text { subunit }\end{array}$ & $\begin{array}{l}\text { Regulation of myotube development. } \\
\text { Role in ventricular cardiomyocyte } \\
\text { expansion and postnatal skeletal } \\
\text { muscle growth and regeneration }\end{array}$ \\
\hline 0.593 & GC37319 & W52024 & RPS15A & Ribosomal protein S15a & $60 S$ ribosomal protein S15A \\
\hline 0.592 & GC34223 & M14199 & $R P S A$ & Ribosomal protein SA & $\begin{array}{l}\text { Required for the assembly and stability } \\
\text { of the } 40 S \text { ribosomal subunit. Cell } \\
\text { surface receptor for laminin. Cell } \\
\text { adhesion to the basement membrane } \\
\text { and activation of signaling transduction }\end{array}$ \\
\hline 0.590 & GC36135 & X99226 & FANCA & $\begin{array}{l}\text { Fanconi anemia, } \\
\text { complementation group A }\end{array}$ & $\begin{array}{l}\text { Interstrand DNA cross-link repair and } \\
\text { maintenance of chromosome stability }\end{array}$ \\
\hline 0.585 & GC28763 & AF016371 & $P P I H$ & $\begin{array}{l}\text { Peptidylprolyl isomerase } \mathrm{H} \\
\text { (cyclophilin } \mathrm{H} \text { ) }\end{array}$ & Protein folding \\
\hline 0.576 & GC30155 & Z23064 & $R B M X$ & $\begin{array}{l}\text { RNA binding motif protein, } \\
\text { X-linked }\end{array}$ & $\begin{array}{l}\text { Regulation of gene transcription and } \\
\text { alternative splicing of several } \\
\text { pre-mRNAs }\end{array}$ \\
\hline 0.575 & GC29002 & M14630 & PTMA & Prothymosin $\alpha$ & $\begin{array}{l}\text { Mediation of immunological resistance } \\
\text { to certain opportunistic infections }\end{array}$ \\
\hline 0.574 & GC34930 & X69391 & RPL6 & Ribosomal protein L6 & $\begin{array}{l}\text { Specifically binds to domain } \mathrm{C} \text { of the } \\
\text { tax-responsive enhancer element in the } \\
\text { long terminal repeat of HTLV-I }\end{array}$ \\
\hline 0.571 & GC27651 & AB007191 & MYCBP & C-myc binding protein & $\begin{array}{l}\text { May control the transcriptional activity } \\
\text { of MYC. Stimulates the activation of E } \\
\text { box-dependent transcription by MYC }\end{array}$ \\
\hline 0.571 & GC29848 & T79616 & UQCRB & $\begin{array}{l}\text { Ubiquinol-cytochrome c } \\
\text { reductase binding protein }\end{array}$ & $\begin{array}{l}\text { A component of the } \\
\text { ubiquinol-cytochrome c reductase } \\
\text { complex (complex III or cytochrome } \\
\text { b-c1 complex), which is part of the } \\
\text { mitochondrial respiratory chain }\end{array}$ \\
\hline 0.570 & GC35323 & U37230 & RPL23A & Ribosomal protein L23a & Binds $26 \mathrm{~S}$ rRNA \\
\hline 0.567 & GC35222 & TARDBP & AL050265 & TAR DNA binding protein & $\begin{array}{l}\text { DNA and RNA-binding protein } \\
\text { regulating transcription and splicing }\end{array}$ \\
\hline-0.612 & GC33001 & U11872 & CXCR2 & $\begin{array}{l}\text { Chemokine (C-X-C motif) } \\
\text { receptor } 2\end{array}$ & IL8 receptor activating neutrophils \\
\hline-0.546 & GC35931 & X13255 & $D B H$ & $\begin{array}{l}\text { Dopamine } \beta \text {-hydroxylase } \\
\text { (dopamine } \beta \text {-monooxygenase) }\end{array}$ & $\begin{array}{l}\text { Activity is enhanced by nerve growth } \\
\text { factor }\end{array}$ \\
\hline-0.545 & GC27591 & D87463 & PHYHIP & $\begin{array}{l}\text { Phytanoyl-CoA 2-hydroxylase } \\
\text { interacting protein }\end{array}$ & $\begin{array}{l}\text { Role in the development of the central } \\
\text { system }\end{array}$ \\
\hline-0.544 & GC28151 & U15780 & ST5 & Suppression of tumorigenicity 5 & $\begin{array}{l}\text { Guanine nucleotide exchange factor } \\
\text { (GEF) activating RAB9A and RAB9B }\end{array}$ \\
\hline
\end{tabular}


TABLE 3 | Continued

\begin{tabular}{|c|c|c|c|c|c|}
\hline $\begin{array}{l}\text { COMPARE } \\
\text { coefficient }\end{array}$ & Pattern ID & $\begin{array}{l}\text { GeneBank } \\
\text { accession }\end{array}$ & Gene symbol & Gene name & Gene function \\
\hline-0.516 & GC31384 & AF035812 & DYNC1LI2 & $\begin{array}{l}\text { Dynein, cytoplasmic } 1 \text {, light } \\
\text { intermediate chain } 2\end{array}$ & $\begin{array}{l}\text { Component of the cytoplasmic dynein } \\
1 \text { complex that is involved cargo } \\
\text { transport }\end{array}$ \\
\hline-0.495 & GC29420 & Z50022 & PTTG1IP & $\begin{array}{l}\text { Pituitary tumor-transforming } 1 \\
\text { interacting protein }\end{array}$ & $\begin{array}{l}\text { Facilitates PTTG1 nuclear translocation } \\
\text { by transcription factor RUNX2 }\end{array}$ \\
\hline-0.479 & GC30117 & W27517 & TMEM109 & Transmembrane protein 109 & $\begin{array}{l}\text { DNA damage response. Protection } \\
\text { against ultraviolet C-induced cell death }\end{array}$ \\
\hline-0.476 & GC38293 & M33680 & $C D 81$ & $\begin{array}{l}\text { Cluster of differentiation } \\
\text { molecule } 81\end{array}$ & $\begin{array}{l}\text { Signal transducer. Viral receptor for } \\
\text { HCV }\end{array}$ \\
\hline-0.476 & GC29175 & AA487755 & FKBP9 & $\begin{array}{l}\text { FK506 binding protein 9, } 63 \\
\text { kDa }\end{array}$ & Protein folding during protein synthesis \\
\hline-0.476 & GC36401 & AB023151 & DIP2C & $\begin{array}{l}\text { DIP2 disco-interacting protein } 2 \\
\text { homologue C (Drosophila) }\end{array}$ & Transcription factor binding \\
\hline-0.474 & GC31394 & AB011171 & PLEKHG3 & $\begin{array}{l}\text { Pleckstrin homology domain } \\
\text { containing, family G (with } \\
\text { RhoGef domain) member } 3\end{array}$ & Rho guanyl-nucleotide exchange factor \\
\hline-0.474 & GC38796 & AF035292 & OBSL1 & Obscurin-like 1 & $\begin{array}{l}\text { Role in the ubiquitin ligase pathway that } \\
\text { regulates Golgi morphogenesis and } \\
\text { dendrite patterning in brain }\end{array}$ \\
\hline-0.473 & GC33621 & Y00285 & IGF2R & $\begin{array}{l}\text { Insulin-like growth factor } 2 \\
\text { receptor }\end{array}$ & $\begin{array}{l}\text { Transport of phosphorylated lysosomal } \\
\text { enzymes from Golgi complex and cell } \\
\text { surface to lysosomes }\end{array}$ \\
\hline-0.472 & GC36838 & R48209 & FAM214B & $\begin{array}{l}\text { Family with sequence similarity } \\
214 \text { member B }\end{array}$ & Function unknown \\
\hline-0.470 & GC35831 & AF104913 & EIF4G1 & $\begin{array}{l}\text { Eukaryotic translation initiation } \\
\text { factor } 4 \gamma 1\end{array}$ & $\begin{array}{l}\text { Component of the elF4F complex, } \\
\text { which is involved in the recruitment of } \\
\text { mRNA to the ribosome }\end{array}$ \\
\hline-0.469 & GC32200 & AL096879 & TMEM184B & Transmembrane protein 184B & Activation of MAP kinase signaling \\
\hline-0.467 & GC31388 & S80562 & CNN3 & Calponin 3, acidic & $\begin{array}{l}\text { Thin filament-associated protein } \\
\text { modulating smooth muscle contraction. } \\
\text { Binds actin, calmodulin, troponin C, } \\
\text { and tropomyosin }\end{array}$ \\
\hline-0.465 & GC32482 & M31724 & PTPN1 & $\begin{array}{l}\text { Protein tyrosine phosphatase, } \\
\text { non-receptor type } 1\end{array}$ & $\begin{array}{l}\text { Role in CKII- and p60c-src-induced } \\
\text { signal transduction cascades. } \\
\text { Regulation of EFNA5-EPHA3 signaling, } \\
\text { which modulates cell reorganization } \\
\text { and cell-cell repulsion. Regulation of } \\
\text { hepatocyte growth factor receptor } \\
\text { signaling by MET dephosphorylation }\end{array}$ \\
\hline-0.461 & GC32085 & AB018333 & SASH1 & $\begin{array}{l}\text { SAM and } \mathrm{SH} 3 \text { domain } \\
\text { containing } 1\end{array}$ & Signal transducer, tumor suppressor \\
\hline-0.459 & GC32336 & X07767 & $P R K A C A$ & $\begin{array}{l}\text { Protein kinase, } \\
\text { cAMP-dependent, catalytic, } \alpha\end{array}$ & $\begin{array}{l}\text { Phosphorylation of cytoplasmic and } \\
\text { nuclear proteins }\end{array}$ \\
\hline
\end{tabular}

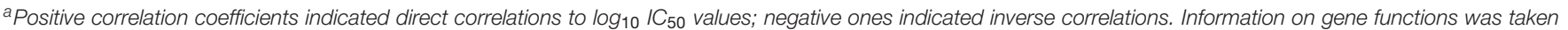

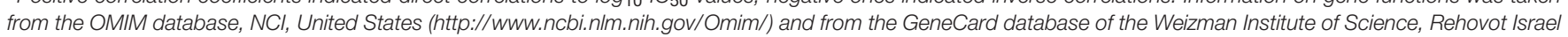
(https://www.genecards.org/).

expressing cells are more sensitive to some drugs than the wildtype counterparts not expressing $\mathrm{ABC}$-transporters. It can be assumed that this process might also takes place in ABCB5expressing cells.

The combination of bromocriptine (20\% $\mathrm{IC}_{50}$ and $\left.40 \% \mathrm{IC}_{50}\right)$ with doxorubicin or with paclitaxel showed synergistic growth inhibition of CEM/ADR5000 cells. Our results are comparable with a previous report, which showed that bromocriptine reversed P-glycoprotein-mediated multidrug resistance in tumor cells (Shiraki et al., 2002). The authors showed that bromocriptine at $10 \mu \mathrm{M}$ reduced the $\mathrm{IC}_{50}$ of doxorubicin in $\mathrm{K} 562$ cells from
9,000 to $270 \mathrm{ng} / \mathrm{mL}$ and that of vincristine in $\mathrm{K} 562$ from 700 to $0.30 \mathrm{ng} / \mathrm{mL}$ (Shiraki et al., 2002).

In the NCI cell line panel, the cellular response to bromocriptine was not associated with expression of $\mathrm{ABC}$ transporters (ABCB1, $\mathrm{ABCB} 5, \mathrm{ABCC} 1$, and $\mathrm{ABCG} 2$ ) and other drug resistance mechanisms (EGFR, mutated TP53, and I$\kappa B)$. However, a significant correlation was found to NF$\kappa B$. Hence, bromocriptine may have the potential to inhibit otherwise drug-resistant tumors in a prolactin-independent manner. NF- $\mathrm{KB}$ may, however, be a resistance mechanisms for bromocriptine. This result was also confirmed by our 


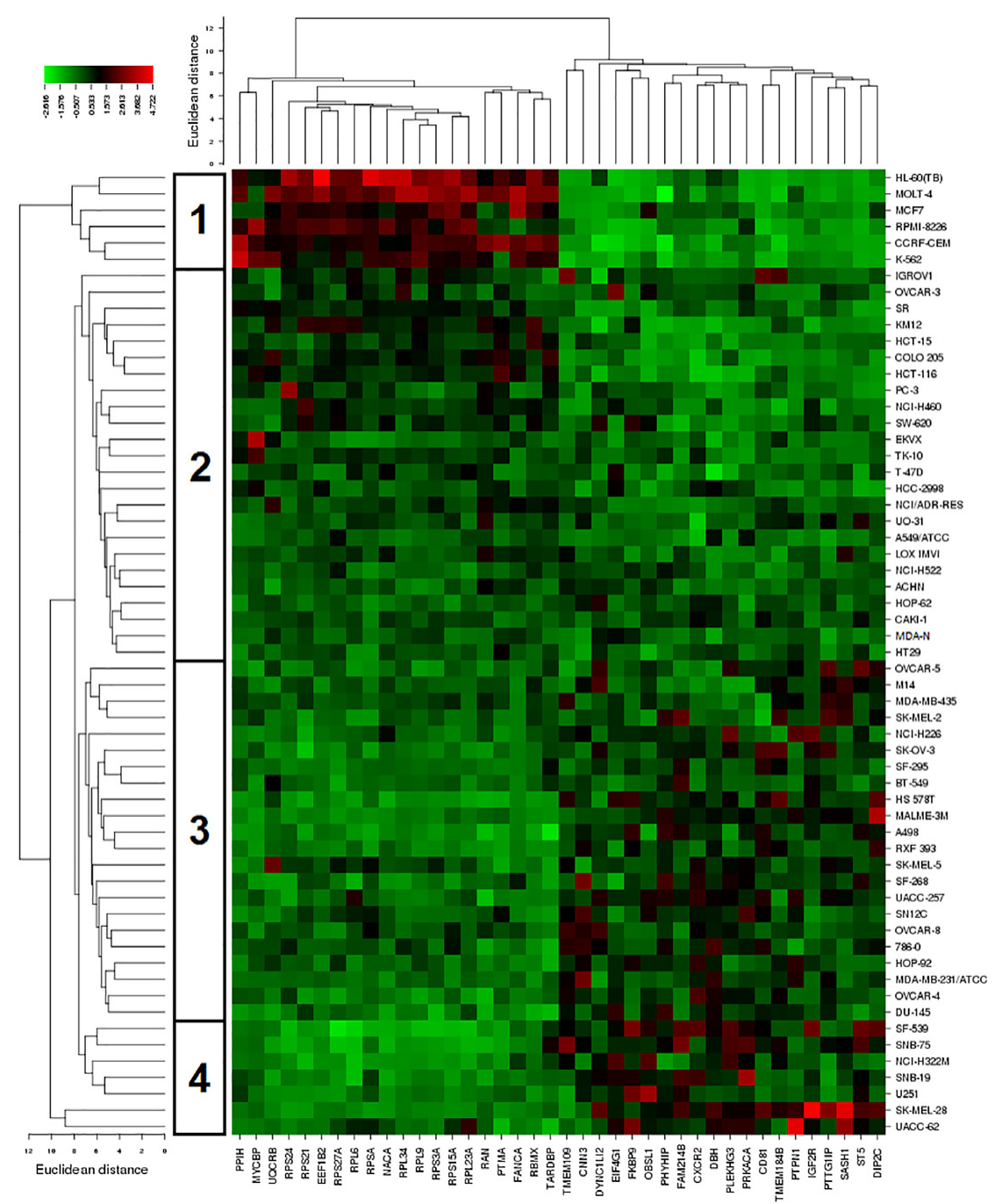

FIGURE 8 | Hierarchical cluster analysis and heat map of expression of genes involved in cellular sensitivity of the NCl cell line panel to bromocriptine.

molecular docking data. Therefore, it is worth to consider bromocriptine for repurposing in cancer therapy. Repurposing of drugs may allow to shorten the long time to approval to the market, which is required for the development of novel drugs, thus, saving time and costs (Ashburn and Thor, 2004).

TABLE 4 | Separation of clusters of $\mathrm{NCl}$ cell lines obtained by hierarchical cluster analyses for bromocriptine shown in Figure $\mathbf{5}$.

\begin{tabular}{|c|c|c|}
\hline & Sensitive & Resistant \\
\hline Partition & $\leq-4.418$ & $>-4.418$ \\
\hline Cluster 1 & 6 & 0 \\
\hline Cluster 2 & 18 & 6 \\
\hline Cluster 3 & 5 & 17 \\
\hline Cluster 4 & 1 & 6 \\
\hline Chi-square test & \multicolumn{2}{|c|}{$P=7.13 \times 10^{-5}$} \\
\hline
\end{tabular}

A practical consideration is, whether the bromocriptine concentration necessary to inhibit tumor growth can be reached in patients. While the serum levels of bromocriptine reached in psychotherapy $(8 \mathrm{ng} / \mathrm{mL})$ may too low to exert cytotoxic effects against cancer cells, a number of publications report on the successful treatment of cancer patients with bromocriptine. This indicates that higher doses are applicable leading to significant reductions of tumor growth in the clinical setting. Thirty infertile women with prolactinoma were treated with $2.5-20 \mathrm{mg} /$ day bromocriptine. After treatment for 24 months, prolactin and tumor diameter were significantly reduced (Hajder et al., 2013). Ten women with metastatic breast cancer and 10 men with metastatic prostate cancer were treated with $2.5 \mathrm{mg}$ p.o. for $24 \mathrm{~h}$, which led to a normalization of prolactin levels in all patients (Lissoni et al., 2000). A clinical phase 2 trial with progressive metastatic prostate cancer revealed that prolactin was suppressed in 10 of 11 patients without serious side effects upon treatment with $3 \times 2.5 \mathrm{mg} /$ day bromocriptine (Horti et al., 1998). Breast 
cancer patients showed significantly reduced prolactin levels and less tumor cells in the S-phase of the cell cycle upon treatment with $1.25-2.5 \mathrm{mg}$ bromocriptine for 5 days (Fentiman et al., 1988). In our study, 20-100 $\mu \mathrm{M}$ were used to induce cytotoxicity and inhibit NF- $\kappa \mathrm{B}$ activation. Further studies are warranted to find the best suited doses of bromocriptine to inhibit tumors in vivo and in the clinic.

Our drug profiling approach with 89 standard anticancer drugs revealed that the NCI cell line panel did not show any correlations between response to bromocriptine and cytostatic drugs that are usually involved in ABC-transportermediated multidrug resistance phenotypes, e.g., anthracyclines, epipodophyllotoxins, camptothecins, Vinca alkaloids, taxanes, etc. This result fits together with the missing correlations of $\log _{10} \mathrm{IC}_{50}$ values for bromocriptine and mRNA and protein expression of ABC-transporters. This was also true for factors that confer not only oncogenic signals, but also resistance to cytostatic drugs, i.e., overexpression of the oncogene EGFR and mutation of the tumor suppressor gene TP53. Hence, bromocriptine is not involved in major drug resistance mechanisms and may therefore be attractive as alternative to treat refractory and otherwise resistant tumors.

Interestingly, we observed significant correlations between cellular response to bromocriptine and anti-hormonal anticancer drugs, i.e., fulvestrant, anastrol, megostrol, and raloxifene. We suggest that the anti-prolactin activity of bromocriptine may share partwise common signal routes with these anti-hormonal drugs.

Furthermore, we investigated molecular determinants of sensitivity and resistance of 60 tumor cell lines using COMPARE analysis of microarray-based transcriptomewide mRNA expression levels of these cell lines (Scherf et al., 2000). Genes from various functional groups such as ribosomal proteins, transcription, translation, DNA repair, DNA damage, protein folding, mitochondrial respiratory chain, and chemokine were detected in our COMPARE analysis. Interestingly, we identified that several genes for ribosomal proteins were upregulated (RPL9, RPS24, RPS3A, RPL34, RPS21, RPS27A, RPS15A, RPSA, RPL6, and RPL23A). Heterozygous inactivating mutations in ribosomal protein genes are related to hematopoietic and developmental abnormalities, activation of p53, and altered risk of cancer in humans (Ajore et al., 2017).

The anti-AML cytotoxic effect of bromocriptine was shown by $\mathrm{D} 4$ dopamine receptor antagonism and other alternative mechanisms (Sachlos et al., 2012). It decreased tumor size by inhibiting the synthesis and secretion of prolactin, and inhibiting angiogenesis in the surrounding tissue (Schettini et al., 1988; Webster, 1999; Acharya et al., 2010). Furthermore, bromocriptine triggered apoptosis in leukemic cells (Liberante et al., 2016).

Cluster analyses were performed to predict, whether a cancer cell line is sensitive or resistant to a cytotoxic compound (Sertel et al., 2012). In our study, all clusters in Table 4 contained sensitive cells lines. However, the distribution differed significantly among the different clusters. The portion of sensitive cells in clusters 1 and 2 was much higher that in clusters 3 and 4. Vice versa, the portion of resistant cell lines in clusters 3 and 4 was much higher than in clusters 1 and 2. Cluster 1 contained $100 \%$ sensitive cell lines and $0 \%$ resistant cells. Cluster 2 contained $75 \%$ sensitive cells and $25 \%$ resistant cell lines. Cluster 3 contained 23\% sensitive cell lines and 77\% resistant cell lines. Cluster 4 contained 14\% sensitive cell lines and 86\% resistant cell lines. This percentage-based distribution clearly showed significant differences between the clusters as confirmed by the chi square test $\left(p=7.3 \times 10^{-5}\right)$. Bromocriptine showed two clusters with predominantly sensitive and two clusters with predominantly resistant cell lines. The prediction of sensitivity or resistance to cytotoxic drugs by mRNA expression profiles can be useful for individualized or precise drugs, since it might provide a chance to know whether a tumor will respond to specific drugs or not.

NF- $\kappa \mathrm{B}$ mediates resistance toward diverse cancer therapeutics by inhibition of apoptosis, and inhibition of NF- $\kappa \mathrm{B}$ sensitizes cancer cells toward anticancer drugs (e.g., doxorubicin and imatinib), cytotoxic phytochemicals (e.g., curcumin), biological agents (e.g., $\beta$-IFN and TRAIL), and radiation (Schwartz et al., 1999; Deeb et al., 2004; Bednarski et al., 2008; Chen et al., 2008; Choi et al., 2008; Lounnas et al., 2009; Tracey et al., 2010). Therefore, NF-кB can be an important target for drug development. We performed molecular docking analyses to study the binding of bromocriptine to NF$\kappa \mathrm{B}, \mathrm{I}-\kappa \mathrm{B}$ kinase $\beta, \mathrm{I}-\kappa \mathrm{B}$ kinase $\beta$-NEMO complex, and NF-кB-DNA complex in silico. Our docking study showed that bromocriptine strongly binds to target proteins and it interacted more strongly with DNA-bound NF- $\kappa$ B than free $N F-\kappa B$, indicating that bromocriptine can inhibit the DNA binding to NF- $\kappa$ B. We demonstrated that bromocriptine decreases NF- $\kappa \mathrm{B}$ activity by SEAP-driven NF- $\kappa \mathrm{B}$ reporter assay.

Our results indicate that bromocriptine can be further investigated as an anticancer repurposing drug.

\section{AUTHOR CONTRIBUTIONS}

E-JS performed cell viability assay, molecular dockings, cluster analyses of microarray data, and NF- $\mathrm{B}$ reporter cell assay and wrote the manuscript. YS generated the ABCB5 transfected cell line. HG wrote and corrected the manuscript. TE organized this study, performed compare and cluster analyses of microarray data, and wrote the manuscript.

\section{SUPPLEMENTARY MATERIAL}

The Supplementary Material for this article can be found online at: https://www.frontiersin.org/articles/10.3389/fphar. 2018.01030/full\#supplementary-material 


\section{REFERENCES}

Acharya, S. V., Gopal, R. A., Menon, P. S., Bandgar, T. R., and Shah, N. S. (2010). Giant prolactinoma and effectiveness of medical management. Endocr. Pract. 16, 42-46. doi: 10.4158/EP09221.OR

Ajore, R., Raiser, D., McConkey, M., Jöud, M., Boidol, B., Mar, B., et al. (2017). Deletion of ribosomal protein genes is a common vulnerability in human cancer, especially in concert with TP53 mutations. EMBO Mol. Med. 9, 498-507. doi: $10.15252 / \mathrm{emmm} .201606660$

Amundson, S. A., Do, K. T., Vinikoor, L. C., Lee, R. A., Koch-Paiz, C. A., Ahn, J., et al. (2008). Integrating global gene expression and radiation survival parameters across the 60 cell lines of the National Cancer Institute Anticancer Drug Screen. Cancer Res. 68, 415-424. doi: 10.1158/0008-5472.CAN-07-2120

Ashburn, T. T., and Thor, K. B. (2004). Drug repositioning: identifying and developing new uses for existing drugs. Nat. Rev. Drug Discov. 3, 673-683. doi: $10.1038 / \mathrm{nrd} 1468$

Baldwin, A. S. (2001). Control of oncogenesis and cancer therapy resistance by the transcription factor NF-kappaB. J. Clin. Invest. 107, 241-246. doi: 10.1172/ JCI11991

Bednarski, B. K., Ding, X., Coombe, K., Baldwin, A. S., and Kim, H. J. (2008). Active roles for inhibitory kappaB kinases alpha and beta in nuclear factor-kappaBmediated chemoresistance to doxorubicin. Mol. Cancer Ther. 7, 1827-1835. doi: 10.1158/1535-7163.MCT-08-0321

Bellera, C. L., Balcazar, D. E., Alberca, L., Labriola, C. A., Talevi, A., and Carrillo, C. (2013). Application of computer-aided drug repurposing in the search of new cruzipain inhibitors: discovery of amiodarone and bromocriptine inhibitory effects. J. Chem. Inf. Model. 53, 2402-2408. doi: 10.1021/ci400284v

Brunton, P. J., and Russell, J. A. (2010). Endocrine induced changes in brain function during pregnancy. Brain Res. 1364, 198-215. doi: 10.1016/j.brainres. 2010.09.062

Casanueva, F. F., Molitch, M. E., Schlechte, J. A., Abs, R., Bonert, V., Bronstein, M. D., et al. (2006). Guidelines of the Pituitary Society for the diagnosis and management of prolactinomas. Clin. Endocrinol. 65, 265-273. doi: 10.1111/j. 1365-2265.2006.02562.x

Chen, W., Wang, X., Bai, L., Liang, X., Zhuang, J., and Lin, Y. (2008). Blockage of NF-kappaB by IKKbeta- or RelA-siRNA rather than the NF-kappaB supersuppressor IkappaBalpha mutant potentiates adriamycin-induced cytotoxicity in lung cancer cells. J. Cell. Biochem. 105, 554-561. doi: 10.1002/jcb.21856

Choi, B. H., Kim, C. G., Lim, Y., Shin, S. Y., and Lee, Y. H. (2008). Curcumin downregulates the multidrug-resistance mdr1b gene by inhibiting the PI3K/Akt/NF kappa B pathway. Cancer Lett. 259, 111-118. doi: 10.1016/j.canlet.2007.10.003

Cincotta, A. H., and Meier, A. H. (1996). Bromocriptine (Ergoset) reduces body weight and improves glucose tolerance in obese subjects. Diabetes Care 19, 667-670. doi: 10.2337/diacare.19.6.667

Darvishi, B., Farahmand, L., Eslami-S, Z., and Majidzadeh-A, K. (2017). NFkappaB as the main node of resistance to receptor tyrosine kinase inhibitors in triple-negative breast cancer. Tumour Biol. 39:1010428317706919. doi: 10.1177/ 1010428317706919

Dawood, M., Hamdoun, S., and Efferth, T. (2018). Multifactorial modes of action of arsenic trioxide in cancer cells as analyzed by classical and network pharmacology. Front. Pharmacol. 9:143. doi: 10.3389/fphar.2018.00143

Deeb, D., Jiang, H., Gao, X., Hafner, M. S., Wong, H., Divine, G., et al. (2004). Curcumin sensitizes prostate cancer cells to tumor necrosis factor-related apoptosis-inducing ligand/Apo2L by inhibiting nuclear factor-kappaB through suppression of IkappaBalpha phosphorylation. Mol. Cancer Ther. 3, 803-812.

Defronzo, R. A. (2009). Banting Lecture. From the triumvirate to the ominous octet: a new paradigm for the treatment of type 2 diabetes mellitus. Diabetes 58, 773-795. doi: 10.2337/db09-9028

Dhanalakshmi, S., Singh, R. P., Agarwal, C., and Agarwal, R. (2002). Silibinin inhibits constitutive and TNFalpha-induced activation of NF-kappaB and sensitizes human prostate carcinoma DU145 cells to TNFalpha-induced apoptosis. Oncogene 21, 1759-1767. doi: 10.1038/sj.onc.1205240

Doyle, L. A., Weidong, Y., Abruzzo, L. V., Tammy, K., Yongming, G., Rishi, A. K., et al. (1998). A multidrug resistance transporter from human MCF-7 breast cancer cells. Proc. Natl. Acad. Sci. U.S.A. 95, 15665-15670. doi: 10.1073/pnas. 95.26.15665

Efferth, T., Herrmann, F., Tahrani, A., and Wink, M. (2011). Cytotoxic activity of secondary metabolites derived from Artemisia annua L. towards cancer cells in comparison to its designated active constituent artemisinin. Phytomedicine 18, 959-969. doi: 10.1016/j.phymed.2011.06.008

Efferth, T., Sauerbrey, A., Olbrich, A., Gebhart, E., Rauch, P., Weber, H. O., et al. (2003). Molecular modes of action of artesunate in tumor cell lines. Mol. Pharmacol. 64, 382-394. doi: 10.1124/mol.64.2.382

Evans, A., Bates, V., Troy, H., Hewitt, S., Holbeck, S., Chung, Y. L., et al. (2008). Glut-1 as a therapeutic target: increased chemoresistance and HIF1 -independent link with cell turnover is revealed through COMPARE analysis and metabolomic studies. Cancer Chemother. Pharmacol. 61, 377-393. doi: 10.1007/s00280-007-0480-1

Ezrokhi, Luo, S., Trubitsyna, Y., and Cincotta, A. H. (2014). Neuroendocrine and metabolic components of dopamine agonist amelioration of metabolic syndrome in SHR rats. Diabetol. Metab. Syndr. 6:104. doi: 10.1186/1758-59966-104

Fagan, V., Sarah, B., Michael, P. C., and Fawaz, A. (2010). One-pot double intramolecular homolytic aromatic substitution routes to dialicyclic ring fused imidazobenzimidazolequinones and preliminary analysis of anticancer activity. Org. Biomol. Chem. 8, 3149-3156. doi: 10.1039/c003511d

Fentiman, I. S., Chaudary, M. A., Wang, D. Y., Brame, K., Camplhjohn, R. S., and Millis, R. R. (1988). Perioperative bromocriptine adjuvant treatment for operable breast cancer. Lancet 1, 609-610. doi: 10.1016/S0140-6736(88) 91413-4

Franken, N. A., Hans, M. R., Jan, S., Jaap, H., Chris, and van, B. (2006). Clonogenic assay of cells in vitro. Nat. Protoc. 1, 2315-2319. doi: 10.1038/nprot.2006.339

Goldstein, M. (1980). Ergot Compounds and Brain Function : Neuroendocrine and Neuropsychiatric Aspects. Advances in Biochemical Psychopharmacology. New York, NY: Raven Press, 413.

Gottesman, M. M., and Pastan, I. (1993). Biochemistry of multidrug resistance mediated by the multidrug transporter. Annu. Rev. Biochem. 62, 385-427. doi: 10.1146/annurev.bi.62.070193.002125

Hajder, M., Hajder, E., Dervisefendic, M., Samardzic, R., and Alic, E. (2013). Prolactinomas in infertile women: clinical and endocrine characteristics before and after 24 months of treatment with bromocriptine. Med. Arch. 67, 181-184. doi: 10.5455/medarh.2013.67.181-184

Hayden, M. S., and Ghosh, S. (2008). Shared principles in NF-kappaB signaling. Cell 132, 344-362. doi: 10.1016/j.cell.2008.01.020

Horti, J., Figg, W. D., Weinberger, B., Kohler, D., and Sartor, O. (1998). A phase II study of bromocriptine in patients with androgen-independent prostate cancer. Oncol. Rep. 5, 893-896. doi: 10.3892/or.5.4.893

Hutchison, D. J. (1963). Cross resistance and collateral sensitivity studies in cancer chemotherapy. Adv. Cancer Res. 7, 235-250. doi: 10.1016/S0065-230X(08) 60984-7

Kadioglu, O., and Efferth, T. (2015). Pharmacogenomic characterization of cytotoxic compounds from Salvia officinalis in cancer cells. J. Nat. Prod. 78, 762-775. doi: 10.1021/np501007n

Kadioglu, O., Jacob, S., Bohnert, S., Naß, J., Saeed, M. E., Khalid, H., et al. (2016). Evaluating ancient Egyptian prescriptions today: anti-inflammatory activity of Ziziphus spina-christi. Phytomedicine 23, 293-306. doi: 10.1016/j.phymed.2016. 01.004

Kawanobe, T., Kogure, S., Nakamura, S., Sato, M., Katayama, K., Mitsuhashi, J., et al. (2012). Expression of human ABCB5 confers resistance to taxanes and anthracyclines. Biochem. Biophys. Res. Commun. 418, 736-741. doi: 10.1016/j. bbrc.2012.01.090

Kimmig, A., Gekeler, V., Neumann, M., Frese, G., Handgretinger, R., Kardos, G., et al. (1990). Susceptibility of multidrug-resistant human leukemia cell lines to human interleukin 2-activated killer cells. Cancer Res. 50, 6793-6799.

Kuete, V., Cedric, F. T., Flora, T. M., Veronique, P. B., and Efferth, T. (2016a). Cytotoxicity of methanol extracts of 10 Cameroonian medicinal plants towards multi-factorial drug-resistant cancer cell lines. BMC Complement. Altern. Med. 16:267. doi: 10.1186/s12906-016-1253-3

Kuete, V., Joachim, K. D., Igor, K. V., Aimé, G. F., and Efferth, T. (2016b). Cytotoxicity of methanol extracts of Annona muricata, Passiflora edulis and nine other Cameroonian medicinal plants towards multi-factorial drugresistant cancer cell lines. Springerplus 5:1666. doi: 10.1186/s40064-0163361-4

Kvernmo, T., Hartter, S., and Burger, E. (2006). A review of the receptor-binding and pharmacokinetic properties of dopamine agonists. Clin. Ther. 28, 10651078. doi: 10.1016/j.clinthera.2006.08.004 
Lee, J. J., Maiying, K., Gregory, D. A., and Roni, L. (2007). Interaction index and different methods for determining drug interaction in combination therapy. J. Biopharm. Stat. 17, 461-480. doi: 10.1080/10543400701199593

Liberante, F. G., Pouryahya, T., McMullin, M. F., Zhang, S. D., and Mills, K. I. (2016). Identification and validation of the dopamine agonist bromocriptine as a novel therapy for high-risk myelodysplastic syndromes and secondary acute myeloid leukemia. Oncotarget 7, 6609-6619. doi: 10.18632/oncotarget.6773

Lissoni, P., Mandalà, M., Giani, L., Malugani, F., Secondino, S., Zonato, S., et al. (2000). Efficacy of bromocriptine in the treatment of metastatic breast cancerand prostate cancer-related hyperprolactinemia. Neuro Endocrinol. Lett. 21, 405-408.

Lounnas, N., Frelin, C., Gonthier, N., Colosetti, P., Sirvent, A., Cassuto, J. P., et al. (2009). NF-kappaB inhibition triggers death of imatinib-sensitive and imatinibresistant chronic myeloid leukemia cells including T315I Bcr-Abl mutants. Int. J. Cancer 125, 308-317. doi: 10.1002/ijc.24294

Meier, A. H., Cincotta, A. H., and Lovell, W. C. (1992). Timed bromocriptine administration reduces body fat stores in obese subjects and hyperglycemia in type II diabetics. Experientia 48, 248-253. doi: 10.1007/BF01930467

Millan, M. J., Maiofiss, L., Cussac, D., Audinot, V., Boutin, J. A., and NewmanTancredi, A. (2002). Differential actions of antiparkinson agents at multiple classes of monoaminergic receptor. I. A multivariate analysis of the binding profiles of 14 drugs at 21 native and cloned human receptor subtypes. J. Pharmacol. Exp. Ther. 303, 791-804. doi: 10.1124/jpet.102.039867

Morgan, M. J., and Liu, Z. G. (2011). Crosstalk of reactive oxygen species and NF-kappaB signaling. Cell Res. 21, 103-115. doi: 10.1038/cr.2010.178

Muralikrishnan, D., and Mohanakumar, K. P. (1998). Neuroprotection by bromocriptine against 1-methyl-4-phenyl-1,2,3,6-tetrahydropyridine-induced neurotoxicity in mice. FASEB J. 12, 905-912. doi: 10.1096/fasebj.12.10.905

Murteira, S., Ghezaiel, Z., Karray, S., and Lamure, M. (2013). Drug reformulations and repositioning in pharmaceutical industry and its impact on market access: reassessment of nomenclature. J. Mark. Access Health Policy 1, 1-20. doi: 10. 3402/jmahp.v1i0.21131

O'Brien, J., Wilson, I., Orton, T., and Pognan, F. (2000). Investigation of the Alamar Blue (resazurin) fluorescent dye for the assessment of mammalian cell cytotoxicity. Eur. J. Biochem. 267, 5421-5426. doi: 10.1046/j.1432-1327.2000. 01606.x

Pijl, H., Ohashi, S., Matsuda, M., Miyazaki, Y., Mahankali, A., Kumar, V., et al. (2000). Bromocriptine: a novel approach to the treatment of type 2 diabetes. Diabetes Care 23, 1154-1161. doi: 10.2337/diacare.23.8.1154

Radad, K., Gille, G., and Rausch, W. D. (2005). Short review on dopamine agonists: insight into clinical and research studies relevant to Parkinson's disease. Pharmacol. Rep. 57, 701-712.

Rivero-Segura, N. A., Flores-Soto, E., de la Cadena, S. G., Coronado-Mares, I., Gomez-Verjan, J. C., Ferreira, D. G., et al. (2017). Prolactin-induced neuroprotection against glutamate excitotoxicity is mediated by the reduction of $\left[\mathrm{Ca}^{+}\right] \mathrm{i}$ overload and NF-kappa B activation. PLoS One 12:e176910. doi: 10.1371/journal.pone.0176910

Sachlos, E., Risueño, R. M., Laronde, S., Shapovalova, Z., Lee, J. H., Russell, J., et al. (2012). Identification of drugs including a dopamine receptor antagonist that selectively target cancer stem cells. Cell 149, 1284-1297. doi: 10.1016/j.cell.2012. 03.049

Saeed, M., Kadioglu, O., Khalid, H., Sugimoto, Y., and Efferth, T. (2015). Activity of the dietary flavonoid, apigenin, against multidrug-resistant tumor cells as determined by pharmacogenomics and molecular docking. J. Nutr. Biochem. 26, 44-56. doi: 10.1016/j.jnutbio.2014.09.008

Sandoval, D., Cota, D., and Seeley, R. J. (2008). The integrative role of CNS fuelsensing mechanisms in energy balance and glucose regulation. Annu. Rev. Physiol. 70, 513-535. doi: 10.1146/annurev.physiol.70.120806.095256

Scherf, U., Ross, D. T., Waltham, M., Smith, L. H., Lee, J. K., Tanabe, L., et al. (2000). A gene expression database for the molecular pharmacology of cancer. Nat. Genet. 24, 236-244. doi: 10.1038/73439
Schettini, G., Lombardi, G., Merola, B., Miletto, P., Fariello, C., Cirillo, S., et al. (1988). Effectiveness of a single injectable dose of bromocriptine long acting in the treatment of macroprolactinomas. J. Endocrinol. Invest. 11, 47-51. doi: 10.1007/BF03350096

Schwartz, S. A., Hernandez, A., and Mark Evers, B. (1999). The role of NFkappaB/IkappaB proteins in cancer: implications for novel treatment strategies. Surg. Oncol. 8, 143-153. doi: 10.1016/S0960-7404(00)00012-8

Sertel, S., Eichhorn, T., Sieber, S., Sauer, A., Weiss, J., Plinkert, P. K., et al. (2012). Factors determining sensitivity and resistance of tumor cells to arsenic trioxide. PLoS One 7:e35584. doi: 10.1371/journal.pone.0035584

Shiraki, N., Okamura, K., Tokunaga, J., Ohmura, T., Yasuda, K., Kawaguchi, T., et al. (2002). Bromocriptine reverses P-glycoprotein-mediated multidrug resistance in tumor cells. Jpn. J. Cancer Res. 93, 209-215. doi: 10.1111/j.13497006.2002.tb01260.x

Tan, E. K., and Jankovic, J. (2001). Choosing dopamine agonists in Parkinson's disease. Clin. Neuropharmacol. 24, 247-253. doi: 10.1097/00002826200109000-00001

Torner, L., Toschi, N., Pohlinger, A., Landgraf, R., and Id. (2001). Anxiolytic and anti-stress effects of brain prolactin: improved efficacy of antisense targeting of the prolactin receptor by molecular modeling. J. Neurosci. 21, 3207-3214. doi: 10.1523/JNEUROSCI.21-09-03207.2001

Tracey, L., Streck, C. J., Du, Z., Williams, R. F., Pfeffer, L. M., Nathwani, A. C., et al. (2010). NF-kappaB activation mediates resistance to IFN beta in MLLrearranged acute lymphoblastic leukemia. Leukemia 24, 806-812. doi: 10.1038/ leu. 2010.2

Webster, J. (1999). Dopamine agonist therapy in hyperprolactinemia. J. Reprod. Med. 44(Suppl. 12), 1105-1110.

Weil, C. (1986). The safety of bromocriptine in long-term use: a review of the literature. Curr. Med. Res. Opin. 10, 25-51. doi: 10.1185/0300799860911 1089

Weinstein, J. N., Myers, T. G., O'Connor, P. M., Friend, S. H., Fojo, T., Kohn, K. W., et al. (1997). An information-intensive approach to the molecular pharmacology of cancer. Science 275, 343-349. doi: 10.1126/science.275. 5298.343

Wosikowski, K., Schuurhuis, D., Johnson, K., Paull, K. D., Myers, T. G., Weinstein, J. N., et al. (1997). Identification of epidermal growth factor receptor and c-erbB2 pathway inhibitors by correlation with gene expression patterns. J. Natl. Cancer Inst. 89, 1505-1515. doi: 10.1093/jnci/89.20.1505

$\mathrm{Wu}, \mathrm{K}$., and Bonavida, B. (2009). The activated NF-kappaB-Snail-RKIP circuitry in cancer regulates both the metastatic cascade and resistance to apoptosis by cytotoxic drugs. Crit. Rev. Immunol. 29, 241-254. doi: 10.1615/ CritRevImmunol.v29.i3.40

Yoshikawa, T., Minamiyama, Y., Naito, Y., and Kondo, M. (1994). Antioxidant properties of bromocriptine, a dopamine agonist. J. Neurochem. 62, 1034-1038. doi: 10.1046/j.1471-4159.1994.62031034.x

Zeino, M., Saeed, M. E., Kadioglu, O., and Efferth, T. (2014). The ability of molecular docking to unravel the controversy and challenges related to P-glycoprotein-a well-known, yet poorly understood drug transporter. Invest. New Drugs 32, 618-625. doi: 10.1007/s10637-014-0098-1

Conflict of Interest Statement: The authors declare that the research was conducted in the absence of any commercial or financial relationships that could be construed as a potential conflict of interest.

Copyright (c) 2018 Seo, Sugimoto, Greten and Efferth. This is an open-access article distributed under the terms of the Creative Commons Attribution License (CC BY). The use, distribution or reproduction in other forums is permitted, provided the original author(s) and the copyright owner(s) are credited and that the original publication in this journal is cited, in accordance with accepted academic practice. No use, distribution or reproduction is permitted which does not comply with these terms. 